\title{
An Autoclave Effect on the Powder of Poly Methylmethacrylate
}

\author{
Manar.N.Y. Nazhat ${ }^{1}$, Tariq.Y.Q. Basshi ${ }^{1}$, Amer.A. Taqa ${ }^{2, *}$ \\ ${ }^{1}$ Department of Prosthodontics, College of Dentistry, University of Mosul \\ ${ }^{2}$ Department of Basic Sciences, College of Dentistry, University of Mosul \\ *Corresponding author: amertaqa@hotmail.com
}

Received May 26, 2014; Revised June 07, 2014; Accepted June 10, 2014

\begin{abstract}
Background: Although most of the physical and mechanical properties of denture base resin polymerized by the conventional heat polymerization have been studied, the effect of autoclave processing on these properties has not been fully determined. The effect of autoclave on acrylic powder has not studied before. Materials and methods: Vertex was the heat - cured acrylic denture base material included in this study. A total of 90 specimens were prepared, the specimens were grouped into three control groups of Vertex acrylic resin which(group A) as curing by conventional water- bath technique $\left(74^{\circ} \mathrm{C}\right.$ for 90 minutes, then boil for 30 minutes, (group B) which curing by water- bath $\left(100^{\circ} \mathrm{C}\right.$ for 30 minutes), and (group C)which curing by autoclave $\left(120^{\circ} \mathrm{C}\right.$ under 1.4 bar for 45 minutes). The other three groups of Vertex acrylic resin after treatment of powder by autoclave in $132{ }^{\circ} \mathrm{C}$ for 4 hours, and then grouped into (A1,B1 andC1) which curing as previously. To study the effect of treatment of powder of acrylic resin byautoclave and the effect of autoclave processing. Three tests were conducted surface roughness (profilometer tester), transverse strength (Instron universal testing machine), and surface hardness (Shore D). The results were analyzed to Descriptive Statistics and ANOVA test. Results: There were no significant differences in surface roughness in all studying groups. There was a highly significant difference in transverse strength test results between studying groups. There was a significant difference in surface hardness test results between studying groups. Conclusions: The treatment of powder of acrylic resin by autoclave had no significant differences in surface roughness, but had a highly significant Difference in transverse strength in all test results, and a significant difference in hardness surface test in group B1. The autoclave processing technique might also be a good alternative to the conventional water- bath processing technique.
\end{abstract}

Keywords: autoclave, transverse, surface roughness, hardness surface

Cite This Article: Manar.N.Y. Nazhat, Tariq.Y.Q. Basshi, and Amer.A. Taqa, “An Autoclave Effect on the Powder of Poly Methylmethacrylate.” International Journal of Dental Sciences and Research, vol. 2, no. 3 (2014): 69-72. doi: 10.12691/ijdsr-2-3-6.

\section{Introduction}

The demand for complete dentures is high due to the increase in life expectancy. Although a variety of resins have been introduced in the dental treatments for the construction of removable partial and complete denture, (PMMA) is the resin of choice for the fabrication of denture bases. It has excellent physical properties [1]. Three fundamental features have contributed to its success: excellent appearance, simple processing technique and easiness of the repair. However, the fracture resistance of (PMMA) during function is law.

Surface roughness provides the adhesion and retention of Candida Albecans, which is of specific importance in denture-induced stomatitis pathogenesis [2,3].

In order to develop stronger denture base materials resistance to fracture, different approaches have been proposed and polymer modified to improve strength properties [4].

Curing procedures have been modified to improve the physical and mechanical properties of resin material.
Different polymerization methods have been used: heat, light, chemical and microwave energy [5].

The water bath processing technique has been the most conventionally used polymerization technique. The use of microwave energy rather than water bath curing which is possible to process acrylic dentures in a very short time, because the surface and the deeper parts of the resin are uniformly and rapidly heated [6].

Polymerization depends on the monomer being attached with the polymer free radical, the more the temperature rises, the faster the molecules and the more complete is the polymerization reaction [7].

Conventional acrylic resin material can be polymerized by autoclave and requires less than $1 \mathrm{hr}$.for polymerization and utilizes conventional equipment.

Polymerization by microwave or by autoclave have shown comparable physical and mechanical properties to the water bath technique.

The aim of the study is to investigate the effect of autoclave on some mechanical properties (PMMA) powder by curing process two cycles of water bath and curing by autoclave. 


\section{Materials and Methods}

The control groups of conventional heat curing denture base material of Vertex Regular Type 1 E-0120, Lot XU 034 LO5 Vertex -Dental by J.V oldenbaneveltin, 623705 HJ Zeist The Netherlands. These control groups were cured by water bath, type Derotor, Multi cure,Italy. Also the control groups were cured by autoclave type Cristofoli, Biosseguranca, Vitale 21.

The modification groups of (PMMA) which are modified the powder of acrylic by autoclave typeHIRAYAMA - HICTVE - HUA-110. Pr.unit 0.1 MPa 1bar, $1.02 \mathrm{Kgf} / \mathrm{cm}^{2}=14.5 \mathrm{Psi}$. The heat applied is $132^{\circ} \mathrm{C}$ and pressure for $4 \mathrm{hr}$. This powder also curing by two different techniques (water bath in two cycles, and by using autoclave)

The two cycles of water bath are:

1 -curing in water bath at $74^{\circ} \mathrm{C}$ for 90 minutes. Then raise the temperature to $100^{\circ} \mathrm{C}$ for 30 minutes.

2- curing in water bath at $100^{\circ} \mathrm{C}$ for 30 minutes.

The curing by autoclave at $120^{\circ} \mathrm{C}$ under 1.4 bar for 45 minutes.

In this vitro study a total of 90 specimenswas prepared, the specimens were grouped into control groups in which processed by both two cycles of water bath and by autoclave, so these groups were: Group A, Group B and Group C, also modification groups processed by both two cycles of water bath and by autoclave, so these groups were: Group $\mathrm{A}_{1}$, Group $\mathrm{B}_{1}$ and Group $\mathrm{C}_{1}$.

\subsection{Roughness Measurements}

Because there is no mention of roughness measurement in the International Standards Organization ISO 1567 for denture base resins, we chose the scanning method for accuracy of the roughness measurements [8].

The specimens were prepared with dimension $(10 \times 10 \times 2)$ $\mathrm{mm}$. The surface roughness $(\mathrm{Ra})$ of specimens were measured using a contact profile meter by using (MarSurf PS1 - Mahr CO. Germany, Explorer V1.20-07).

The method used is to scan a diamond stylus across the surface under a constant load and compute the numeric value representing the Surface roughness which measured in $\mu \mathrm{m}$.

The (Ra) value describes the overall roughness of a surface and is defined as the arithmetic mean value of all absolute distances of the roughness profiles from the center within the measuring length ${ }^{9}$, which can measure a small surface variation by moving a diamond stylus in contact with surface while moving laterally across the specimens under constant pressure and randomly selected reading for each specimen and the mean value was calculated which used for statistical analysis.

\subsection{Transverse Strength Test}

The total number of specimens for transverse strength was 30, 5 specimens in each group (A, B, C, $A_{1}, B_{1}$ and, $\left.C_{1}\right)$, a bar shaped specimen with dimensions of $(65,10,2.5)$ mm respectively.

The transverse strength test was performed using a three point bending testing machine. A three - point testing, design was used whereby the simple specimen beam was centrally loaded at a cross -head speed of $5 \mathrm{~mm}$
/ min over a two - point support span set at $50 \mathrm{~mm}$. The specimen was deflected until rupture occurred. The force required for rupture was recorded and the stress was calculated by means of the following equation:

$$
\text { S = 3.P.L / 2.b.d }{ }^{2}
$$

Where $\mathrm{S}$ is the stress in the outer fibers at Midspan, expressed in MPa; P:Load at a given point on the load deflection curve, expressed in N; L: support span length, expressed in mm; b: width of beam tested, expressed in $\mathrm{mm}$; and d: depth of beam tested, expressed in $\mathrm{mm}$.

The mean transverse strength values and standard deviations were calculated for each group. The statistical significance level was set at $p \leq 0.05$.

\subsection{Indentation Hardness Test}

The specimens were prepared with dimensions of $(30,15,3) \mathrm{mm}$ (length, width, and thickness) respectively. Five specimens from each of groups $\left(A, B, C, A_{1}, B_{1}\right.$ and $\mathrm{C}_{1}$ ).

For determination of the micro-hardness using Shore Hardness Test Stand, Model: LD.YJ, No.321205626. To minimize the risk of misreading, due to the work hardness readings were taken in three different locations and the mean value was taken from each specimen.

The indenter used in the form of round steel ball of $1 / 4$ inch in diameter and the sample subject to minor load and the hardness inspector was calibrated according to the manufactures instruction after ' 15 - 20' second.

Hardness measurement have been successfully used as an indirect method of evaluating polymerizing and degree of conversion $[9,10]$.

\section{Results}

\subsection{Surface Roughness Test}

Descriptive statistical analysis revealed non- significant difference between groups of Vertex in both control types (A, B and C) which curing in water bath by two cycles and curing by autoclave, also the modified groups of Vertex $\left(A_{1}, B_{1}\right.$ and $\left.C_{1}\right)$ which curing also in water bath by two cycles and curing by autoclave as were shown in (Table 1).

Table 1. Descriptive Statistics of(Ra) test results

\begin{tabular}{|c|c|c|c|c|c|}
\hline Gr. & Mean & Std. Deviation & Std. Error & Min. & Max \\
\hline A & 1.19267 & 0.404181 & 0.233354 & 0.929 & 1.658 \\
\hline $\mathbf{A}_{\mathbf{1}}$ & 0.98367 & 0.026502 & 0.015301 & 0.965 & 1.014 \\
\hline $\mathbf{B}$ & 1.25033 & 0.336898 & 0.194508 & 0.975 & 1.626 \\
\hline $\mathbf{B}_{\mathbf{1}}$ & 0.96600 & 0.076374 & 0.044095 & 0.878 & 1.015 \\
\hline $\mathbf{C}$ & 0.98500 & 0.109494 & 0.063217 & 0.868 & 1.085 \\
\hline $\mathbf{C}_{\mathbf{1}}$ & 0.96833 & 0.090185 & 0.052068 & 0.875 & 1.055 \\
\hline
\end{tabular}

It was revealed that polymerization in water bath by two cycles and in an autoclave led to a statistically nonsignificant increase $(\mathrm{p}>0.05)$ in $(\mathrm{Ra})$ in two materials. However, there was no statistically significant difference between curing acrylic resin in water bath and curing by the autoclave polymerization system. There were also no 
statistically significant differences between the control groups and modification groups byVertex type of acrylic as shown in (Table 1 and Table 2).

Table 2. F -test by ANOVA table of (Ra) results

\begin{tabular}{|c|c|c|c|c|c|}
\hline & Sum of Squares & df & Mean Square & F & P-value \\
\hline $\begin{array}{c}\text { Between } \\
\text { Groups }\end{array}$ & 0.247 & 5 & 0.049 & 0.978 & 0.469 \\
\hline $\begin{array}{c}\text { Within } \\
\text { Groups }\end{array}$ & 0.607 & 12 & 0.051 & & \\
\hline Total & 0.854 & 17 & & & \\
\hline
\end{tabular}

\subsection{Transverse Strength Test}

Descriptive statistical analysis revealed a significant increase in transverse strength in control groups (A, B and C ) which curing in autoclave as compared of curing by water bath in two cycles but there was no statistically difference in control groups which curing in water bath. There were statistical differences in transverse strength between the control groups and modification groups by Vertex type of acrylic. There were no statistically difference in modification groups of acrylic $\left(A_{1}\right.$ and $B_{1}$ ) which were polymerized by water bath in two cycles, but there were statistical differences in modification groups when polymerized by autoclave $\left(\mathrm{A}_{1}, \mathrm{~B}_{1}\right.$ and $\left.\mathrm{C}_{1}\right)$. They are statistically significant differences $(p \leq 0.05)$ between control groups and modification groups $\left(\mathrm{C}\right.$ and $\left.\mathrm{C}_{1}\right)$ which polymerized by autoclave as shown in (Table 3 and Table 4).

Table 3. Descriptive Statistics of Transverse Strength test results

\begin{tabular}{|c|c|c|c|c|c|}
\hline & Mean & $\begin{array}{c}\text { Std. } \\
\text { Deviation }\end{array}$ & $\begin{array}{c}\text { Standard } \\
\text { Error }\end{array}$ & Min. & Max \\
\hline A & 78.242 & 1.31306 & 0.58722 & 76.80 & 80.32 \\
\hline $\mathrm{A}_{1}$ & 97.404 & 1.78137 & 0.79665 & 94.91 & 99.45 \\
\hline B & 76.374 & 2.64317 & 1.18206 & 72.33 & 78.79 \\
\hline $\mathrm{B}_{1}$ & 93.988 & 1.93686 & 0.86619 & 91.55 & 95.49 \\
\hline C & 87.460 & 2.04076 & 0.91266 & 84.45 & 89.95 \\
\hline $\mathrm{C}_{1}$ & 113.198 & 1.63394 & 0.73072 & 110.77 & 115.22 \\
\hline
\end{tabular}

Table 4. F-test by ANOVA table of Transverse Strength results

\begin{tabular}{|c|c|c|c|c|c|}
\hline & $\begin{array}{c}\text { Sum of } \\
\text { Squares }\end{array}$ & df & $\begin{array}{c}\text { Mean } \\
\text { Square }\end{array}$ & F & P- value \\
\hline $\begin{array}{c}\text { Between } \\
\text { Groups }\end{array}$ & 4659.173 & 5 & 931.835 & 248.825 & $0.000^{*}$ \\
\hline $\begin{array}{c}\text { Within } \\
\text { Groups }\end{array}$ & 89.878 & 24 & 3.745 & & \\
\hline Total & 4749.052 & 29 & & & \\
\hline
\end{tabular}

\subsection{Indentation Hardness Test}

Descriptive statistical analysis revealed significant differences in indentation hardness test, and the mean and standard deviation between the control groups and modification groups as were shown in (Table 5). There were no statistically differences in control groups (A, B, C) which polymerized by water bath and autoclave. There were statistical differences in modification group (B1) and other groups (A, B, C, $\mathrm{A}_{1}$ and $\mathrm{C}_{1}$ ).

There has been decreased the mean value of hardness in group B1 to 69.3960 as shown in (Table 5 and Table 6).
Table 5. Descriptive Statistics of Surface Hardness test results

\begin{tabular}{|c|c|c|c|c|c|}
\hline & Mean & Std. Deviation & Std. Error & Min. & Max \\
\hline A & 83.0960 & 2.23623 & 1.00007 & 80.66 & 85.33 \\
\hline $\mathrm{A}_{1}$ & 79.7300 & 3.04959 & 1.36382 & 74.33 & 81.33 \\
\hline $\mathrm{B}$ & 80.1960 & 1.81913 & 0.81354 & 78.33 & 82.66 \\
\hline $\mathrm{B}_{1}$ & 69.3960 & 5.42552 & 2.42636 & 60.66 & 74.00 \\
\hline $\mathrm{C}$ & 82.2620 & 4.09923 & 1.83323 & 78.33 & 88.33 \\
\hline $\mathrm{C}_{1}$ & 80.3300 & 2.52774 & 1.13044 & 77.33 & 84.33 \\
\hline
\end{tabular}

Table 6. F - test by ANOVA table of Surface Hardness test results

\begin{tabular}{|c|c|c|c|c|c|}
\hline & $\begin{array}{c}\text { Sum of } \\
\text { Squares }\end{array}$ & df & $\begin{array}{c}\text { Mean } \\
\text { Square }\end{array}$ & F & P- value \\
\hline $\begin{array}{c}\text { Between } \\
\text { Groups }\end{array}$ & 616.084 & 5 & 123.217 & 10.525 & $.000^{*}$ \\
\hline $\begin{array}{c}\text { Within } \\
\text { Groups }\end{array}$ & 280.957 & 24 & 11.707 & & \\
\hline Total & 897.042 & 29 & & & \\
\hline
\end{tabular}

\section{Discussion}

An autoclave is a pressurized device designed to heat aqueous solutions above their boiling point to achieve sterilization. The autoclave is widely used in microbiology, medicine, dentistry and metallurgy.

The term autoclave is also used in processing materials by elevated temperature and pressure.

The results of this study showed that when the acrylic resin material was subjected to autoclave polymerization, a statistically non-significant increase occurred in surface roughness when compared with water bath polymerization by two cycles.There were a statically non- significant differences in surface roughness value between the control and modification groups. The surface roughness of a material used for removable prostheses is of importance because it affects, directly or indirectly, retention, staining resistance, plaque accumulation, oral tissue health, and patient comfort $[11,12]$.

The surface roughness of the denture base acrylic resin was not affected by polymerization methods and without adverse effects on the surface roughness of the material.

$\mathrm{Ra}$ value is possible related to the air bubbles incorporated into the material during mixing were clustered close to the surface, contributing to the higher roughness.

The transverse strength test, one of the mechanical strength tests, is especially useful in comparing denture base materials in which a stress is applied to the denture during mastication [13].

The transverse strength is a combination of compressive, tensile and shear strength, all of which directly reflect the stiffness and resistance of a material to fracture [14].

In this study the reason for the lower transverse strength value of groups (A and B)compared with other groups might be due to the presence of the porosities and common defects and internal voids often result and internal porosities concentrated stresses in the matrix and contributed to the formation of microcracks under loading [15]. Increased degree of conversion may serve to increase the bulk flexural and fatigue strength of groups ( $\mathrm{C}$ and $\left.\mathrm{C}_{1}\right)$. 
The modification groups $\left(A_{1}, B_{1}\right.$ and $\left.C_{1}\right)$ were shown to increase in transverse strength in both water bath and autoclave curing, but the control group (C) was higher value than control groups (A and B).

Hardness may be defined as the resistance to permanent surface indentation or penetration. Shore (D) hardness tester is suitable for measuring the hardness of acrylic resin. The results show that there was a significant difference in the surface hardness between groups and the group $\left(B_{1}\right)$ had the lowest value at 69.3960 but there were no differences between other groups with polymerized by autoclave and water bath. The results coincide with the results obtained by Ming et al [15] when the resin polymerized in autoclave with different pressure and time, the results shown no statically significant differences between the autoclave and conventional polymerization methods.

The hardness of the denture base materials may undergo changes due to continued polymerization reaction [16].

\section{Conclusions}

Within the limitation in this study, concluded the following:

-Treatment of powder of acrylic by autoclave have no significant differencesin surface roughness of all groups.

-Treatment of powder of acrylic by autoclave have significant differencesin transverse strength of all groups.

-Treatment of powder of acrylic resin by autoclave have a significant decrease in hardness value in group $B_{1}$.

\section{References}

[1] Jagger DC, Jagger RG, Allen SM and Harrison A. An investigation into the transverse and impact strength of high strength denture base acrylic resin. Journal of Oral Rehabilitation. 2002:29(3):263-267

[2] Nikawa H, Sadamori S, Hamada T, Satao N, Okuda K. Non specific adherence of Candida species to surface modified glass. J Med Vet Mycol 1989; 27: 269-271.

[3] Nikawa H, Hamada T. Binding of salivary or serum proteins to Candida albicans in vitro. Arch Oral Biol 1990; 17: 138-144.

[4] Mang TR Jr, Latta MA. Physical properties of four acrylic denture base resin. Journal Contemporary Dental Practice 2005; 15(6): 93-100.

[5] Azzari MJ, Cortizo MS, Alessandrini JL. Effect of the curing conditions on the properties of an acrylic denture base resin microwave polymerized. J Dent ; 2003; 31: 463-468.

[6] Banerjee R, Banerjee S, Prabhudesai PS, Bhide SV. Influence of the processing technique on the flexural fatigue strength of denture base resins: J Prosthet Dent 2010.21:391-395.

[7] Memon MS, Yunus N, Abdul Razak AA, Some mechanical properties of a highly cross-linked, microwave polymerized, injection-molded denture base polymer. International Journal of Prosthodontics 2001.14(3): 214-218.

[8] Whitehead SA, Shearer AC, Watts DC, Wilson NHF. Comparison of methods for measuring surface roughness of ceramic. J Oral Rehabil. 1995; 22: 421-427.

[9] Lee SY, Lai YL, Hsu TS. Influence of polymerization conditions on monomer elution and micro-hardness of autopolymerized polymethyl methacrylate resin. EurJ Oral Sci. 2002; 110: 179-183.

[10] Waters MG, Williams DW, Jagger RG, Lewis MAO. Adherance of Candida albicans to experimental denture soft lining materials. J Prosthet Dent 1997; 77: 306-312.

[11] Ravnholt G, Kabber S. Surface roughness of oral mucosa and its reproduction in dental materials. J Dent 1994; 22: 169-174.

[12] Craig RG. Restorative Dental Materials. $11^{\text {th }}$ ed . St Louis, MO: Mosby; 2002: pp.87-88.

[13] Anusavise KJ. Philips' Science of Dental Materials. $11^{\text {th }}$ ed. St Louis, MO: Saundders; 2003: p.737.

[14] Lai CP, Tsia MH, Chen M, Chang HS, Tay HH. Morphology and properties of denture acrylic resins cured by microwave energy and conventional water bath. Dental Materials 2004, 20(2): 133141.

[15] Ming XC, Changxi S, Weishou H. Rapid processing procedure for heat polymerization of poly (methylmethacrylate) in a pressure cooker with automatic controls. J Prosthet Dent 1996; 76: 445-7.

[16] Azevado MJ, Machado AL, Vergani CE, Giampaolo ET, Pavarina AC. (2005): Hardness of denture base and hard chair - side reline acrylic resins. J Appl Oral Sci; 3: 291-5. 